\title{
The identity and witness of Arab pre-Islamic Arab Christianity: The Arabic language and the Bible
}

\begin{tabular}{|c|c|}
\hline $\begin{array}{l}\text { Author: } \\
\text { David D. Graft }\end{array}$ & \\
\hline $\begin{array}{l}\text { Affiliations: } \\
{ }^{1} \text { The Lutheran } \\
\text { Seminary at PI } \\
\text { United States }\end{array}$ & $\begin{array}{l}\text { Theological } \\
\text { iladelphia, } \\
\text { f America }\end{array}$ \\
\hline $\begin{array}{l}{ }^{2} \text { Department } \\
\text { Testament Stu } \\
\text { of Theology, U } \\
\text { Pretoria, Sout }\end{array}$ & $\begin{array}{l}\text { f New } \\
\text { dies, Faculty } \\
\text { niversity of } \\
\text { Africa. }\end{array}$ \\
\hline $\begin{array}{l}\text { Note: } \\
\text { The Reverend } \\
\text { D. Grafton is A } \\
\text { Professor of Is } \\
\text { and Christian- } \\
\text { Relations and } \\
\text { of Graduate St } \\
\text { the Lutheran } \\
\text { Seminary in Pr } \\
\text { (USA). Profess } \\
\text { is a member o } \\
\text { International } \\
\text { Board of HTS } \\
\text { Studies/Theolc } \\
\text { and a research } \\
\text { of Prof. Dr Ano } \\
\text { Aarde, honora } \\
\text { at the Faculty } \\
\text { University of P } \\
\text { (South Africa). }\end{array}$ & $\begin{array}{l}\text { Dr David } \\
\text { ssociate } \\
\text { amic Studies } \\
\text { Muslim } \\
\text { Director } \\
\text { udies at } \\
\text { heological } \\
\text { iladelphia } \\
\text { r Grafton } \\
\text { the } \\
\text { dvisory } \\
\text { eologiese } \\
\text { gical Studies } \\
\text { associate } \\
\text { ries G. van } \\
\text { y professor } \\
\text { f Theology, } \\
\text { retoria }\end{array}$ \\
\hline $\begin{array}{l}\text { Corresponden } \\
\text { David Grafton }\end{array}$ & ce to: \\
\hline $\begin{array}{l}\text { Email: } \\
\text { dgrafton@|tsp }\end{array}$ & edu \\
\hline $\begin{array}{l}\text { Postal addres } \\
\text { Private Bag X2 } \\
\text { 0028, South A }\end{array}$ & $\begin{array}{l}\text { : Hatfield } \\
\text { rica }\end{array}$ \\
\hline $\begin{array}{l}\text { Dates: } \\
\text { Received: } 15 \\
\text { Accepted: } 30 \\
\text { Published: } 15\end{array}$ & $\begin{array}{l}\text { May } 2014 \\
\text { May } 2014 \\
\text { Tct. } 2014\end{array}$ \\
\hline $\begin{array}{l}\text { How to cite th } \\
\text { Grafton, D.D., } \\
\text { identity and w } \\
\text { pre-Islamic Ar } \\
\text { The Arabic lan } \\
\text { the Bible', HTS } \\
\text { Studies/Theolc } \\
70(1), \text { Art. \#27 } \\
\text { http://dx.doi. } \\
\text { hts.v70i1.2726 }\end{array}$ & $\begin{array}{l}\text { is article: } \\
\text { 2014, 'The } \\
\text { tness of Arab } \\
\text { b Christianity: } \\
\text { juage and } \\
\text { Teologiese } \\
\text { gical Studies } \\
\text { 26, } 8 \text { pages. } \\
\text { rg/10.4102/ }\end{array}$ \\
\hline Read online: & \\
\hline 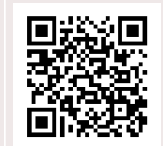 & $\begin{array}{l}\text { Scan this QR } \\
\text { code with your } \\
\text { smart phone or } \\
\text { mobile device } \\
\text { to read online. }\end{array}$ \\
\hline
\end{tabular}

This article argues that Arab Christianity has had a unique place in the history of World Christianity. Rooted in a biblical witness, the origins and history of Arab Christianity have been largely forgotten or ignored. This is not primarily as a result of the fact that the Arab Christian historical legacy has been overcome by Islam. Rather, unlike other early Christian communities, the Bible was never translated into the vernacular of the Arabs. By the 7th century the language of the Qur'an became the primary standard of the Arabic language, which then became the written religious text of the Arabs. This article will explore the identity and witness of the Christian presence in Arabia and claims that the development of an Arabic Bible provides a unique counter-example to what most missiologists have assumed as the basis for the spread of the Christian faith as a result of the translation of the Christian scriptures into a vernacular.

\section{Introduction}

The Great Missionary Age (1792-1914) has been viewed by many Protestant and Evangelical churches in Western Europe and North America as a time through which God provided an opportunity to evangelise the whole world.This was done primarily through the translation, publication and distribution of the Bible. Missionaries were sent out by their mission agencies into the vast reaches of the world, then under Western imperial control, or with the modern technology that made it possible to navigate land, sea and air. Some missionaries explored uncharted territories before the arrival of the 'gunboats' or the 'company', some accompanied the empires, and others followed in their wake; but all utilised the web of imperial infrastructures that made it possible to travel to exotic lands, be supplied for their work and communicate with the agencies and constituencies back home. A major evangelical infrastructure that supported the missionary endeavour within this broader Western network was the industry of Bible publication and distribution. The missionaries, for their part, provided the publishing houses with translations of the Bible in the indigenous languages where they served. In some places, the missionaries put their hand to the plow and did the hard work of learning the local languages to the point that they were competent enough to translate. In most places, however, the missionaries hired local religious leaders or scholars to provide, assist, or correct their own translation of the Bible.

The establishment of the Society for the Preservation of Christian Knowledge (1698), the British and Foreign Bible Society (1804), the Scottish Bible Society (1806), and the American Bible Society (1816) provided an international network of companies that underwrote and sustained missionary activity abroad. The United Bible Societies note that in the 19th century, 446 new versions of the Bible were translated into local languages. In addition, from 1900 to 1980 an additional 1390 new translations were made into local languages (Smalley 1991:34). According to William Smalley (1991), such:

[F]igures provide one of the best indices available to the interrelation between translation and the spread of the church ... this history is a major manifestation of the Spirit of God working in the world and creating the church. (p. 38)

Because the 19th century Protestant missionary endeavour thrived upon this Bible industry of translation, publication and distribution, it has become the commonly accepted narrative that provision of the Bible in the vernacular is a necessary and organic component of the spread of the Christian faith. Reflecting on this assumption, Philip C. Stine (1992) of the United Bible Society wrote:

From the beginning of the Church, as it spread out from the Eastern Mediterranean, its expansion has been paralleled by Bible translation. Sometimes translation preceded and perhaps stimulated the planting of a new church; more often it followed. But translation into vernacular languages was, in most cases, so much a given, something that was simply understood as necessary to the life of the church, that it was rarely questioned. (p. vii) 
Whilst we are not contesting these claims in this research, we would like to question the seemingly corollary opposite claim that without the scripture in local languages, the church has not or cannot thrive. The thesis of this article is that Western missiological scholarship has assumed that a vernacular Scripture demonstrates the depth and growth of a Christian community as opposed to those communities that have not developed an indigenous written scripture. This was the argument of J. Spencer Trimingham (1979:309), who maintained that the evangelistic work of the early Syrian monastics failed to indigenise the faith amongst the Arabs by providing a written Arabic text.

It may certainly be true that Christian scripture is intended to be inherently 'translatable' into vernacular languages and cultures (Sanneh 2008). However, the converse assumption that a Christian community without a vernacular scripture is unorthodox and weak is not necessarily accurate. This article has in mind particularly the identity and witness of the Arab Church. In reviewing the history of Arab Christianity as a multilingual, multicultural, predominantly oral society, we do find the record of a vigorous history, tradition and witness amongst pre-Islamic Arabs without a vernacular written scripture.

\section{The Arabic Bible}

There has been a long standing debate amongst scholars as to whether the Bible was translated into Arabic in preIslamic Arabia or was a response to the coming of Islam in the 7th century. Most recently, Mitri Raheb (2013:130) has argued that the debates over the presence of an Arabic Bible have involved 'an emotional attachment to the issue'. Raheb remarks that there are those Arab Christians who have eagerly desired to prove the existence of a strong Arab Christian presence before the rise of Islam, as well as those who wish to prove that there were no orthodox Arab Christian biblical texts; that Islam utilised heterodox or heretical traditions which led to the Qur'anic views of Jesus, Mary and the Trinity. Finally, Raheb notes the role of certain 'Orientalists' who have been interested in discovering the historic connections between Near Eastern traditions of the Bible and early Islam (Raheb 2013:130-131). ${ }^{1}$ In a previous article, this author has also expressed this problem somewhat differently (Grafton 2013). Having now read Raheb, I prefer his articulation of this issue as 'an emotional attachment'. Arab Christians have a vested interest in proving that their historical roots go back directly to their ancestors as recorded in Acts 2:11. Christian apologists who wish to discredit Islam as having developed from a heretical form of Christianity have their own interest in finding diverse apocryphal noncanonical traditions from which Islam grew.

This important debate aside, scholars of Late Antique Oriental Christianity (that is, from the 2 nd to the 8 th centuries $\mathrm{CE}$ ) have recognised that regardless of whether the Bible was translated into Arabic before or after the coming of Islam,

1.Amongst those scholars to whom Raheb points are, of course, Louis Cheikho, Sami Khalil Samir, and most recently Irfan Shahid. there are no current extant biblical texts from before the 9th century. $^{2}$ A variety of Arabic MSS from the famous library at the St. Catherine's monastery in the Sinai that include portions of the New Testament have all been identified as 9th century works, including Sinai arab. 151, Sinai arab. 155, Sinai arab. 154, Sinai arab. 70, Sinai arab. 72, Sinai arab. 73, Sinai arab. 74, ar ${ }^{\text {pet }}$ (an Arabic codex of the Pauline Epistles), and Gregory-Aland 0136 and 0137. These manuscripts (MSS) or fragments have been studied by a variety of scholars; including Constantine von Tischendorf, Edvard Stenij, Agnes Smith Lewis, Margaret Dunlop Gibson, Anton Baumstark, Arthur Vööbus, Georg Graf, Harvey Staal, Bruce Metzger, and most recently by Hikmat Kachouh (Griffith 1985; Kachouh 2011; see also Atiya 1955). ${ }^{3}$ Kachouh's research has provided a great service to the ongoing discussion of the history of the Arab Bible and Arabic Christianity. His doctoral dissertation, and later published work, has segregated the Arabic versions of the Gospels into families of MSS; those that demonstrate a Syriac, Greek, Latin or Coptic textual origin, or a combination of these languages. Kachouh has argued that the earliest Arabic Gospel text that we now possess is Vatican Arabic Manuscript (MS) 13 from the Mar Saba monastery near Jerusalem that can be dated to around 800 CE. It includes Matthew, Mark and a portion of Luke and was more than likely translated from Syriac (Kachouh 2008; see this discussion in Griffith 2013:114-118).

Probably the most famous of these Arabic texts, however, has been Sinai arab. 154, which was 'discovered' and studied by Ms. Margaret Dunlop Gibson (2003 [1899]) during one of her visits to the St. Catherine's monastery in 1893. This MSS not only includes the Acts of the Apostles and all seven Catholic Epistles translated from a previous Syriac version, but more importantly, the earliest Christian Arabic theological treatise known to date from around $750 \mathrm{CE}$, what has been called On the triune nature of God (Samir 1994; Swanson 1998). Whilst the story of Constantine von Tischendorf's finding and acquisition of the Codex Sinaiticus from the library at St. Catherine's has become the most well-known tale of modern biblical scholarship, the diaries of the Scottish sisters Margaret Dunlop Gibson and Agnes Smith Lewis that include their travels to St. Catherine's, their interactions with the monks of the monastery, and the treasures of the library is a simply delightful tale (Lewis \& Gibson 1893). The inclusion of On the triune nature within Sinai arab. 154 highlights that whilst it is clear we have no remains of an Arabic Bible before the coming of Islam, there are those who have looked at extrabiblical literature for proof of a vibrant and living Arab Christian tradition. The scholarly work of Sidney Griffith, Samir Khalil Samir, Mark Swanson, David Thomas and Sandra T. Keating, amongst others, has advanced the work of Louis Cheikho, Alfred Mingana, Joseph Nassrallah, and

2.For example, Michael the Syrian's, Chronicon from the 12th century refers to the translation undertaken by John, Patriarch of Antioch from 631-648 CE (Chabot translation undertaken by John, Patriarch of Antioch from 631-648 CE (Chabo 1849). There is a reference to the translation of the Bible by Ahmadibn Abdullah ibn Salam in Abu'l-Faraj Muhammad bin Is'haq al-Nadim's Kitab al-Fihrist written in the 10th century (Dodge 1970). Finally, there is the tradition of the early translation of the Latin Vulgate into Arabic by a John of Seville in the 8th century (De Lagarde
1963,2009 ).

3.A quick review of these existing MSS can be found in Metzger (1977:260-265). 
George Graff of previous generations (Grypeou, Swanson \& Thomas 2006). Yet, research into the identity and witness of the pre-Islamic Arabic Church is still in its infancy.

The aforementioned ongoing research on the Arab Bible has demonstrated that the only extant versions of Arabic Christian scripture we currently possess can only be dated to $800 \mathrm{CE}$ at the earliest. The lateness of these MSS has led most biblical textual scholars to relegate the Arabic Bible to a minor branch of textual scholarship. Metzger and Vööbus include these important MSS in their overviews of the texts of the New Testament, however, they do not consider them useful for early biblical textual studies. This assessment has supported a Western assumption that the Arab Church has had little to contribute to the rise of Christianity. We will return to this assumption in our conclusion.

\section{The historical problems of pre-Islamic Arab Christianity}

The question then still remains as to why we do not possess any earlier Arabic biblical texts before the coming of Islam. The development of an Arabic Bible after the coming of Islam in the 7th century would seem to demonstrate that the Arab Christian community felt the need to advance some form of Christian apologetic in response to the public use of an Arabic Qur'an. Sidney Griffith has noted the important 'pastoral problem' of the Arab Christian bishop Theodore Abu Qurrah, the Melkite Bishop of Haran (740-820), who witnessed the dominant culture of his day swing from Christian Syriac to Muslim Arabic. As the Arab Muslims settled into their 2nd century of rule in the Near East, and with the rise of the second familial imperial rule of the 'Abbasids from 750-1258, there was a certain and gradual Arabization and Islamization of Near Eastern culture. That is, as dominant Arab culture ultimately became Islamicised some two hundred years after the initial Muslim conquest, the translation of the Bible provided the opportunity for a renewed sense of counter-cultural communal identity even as the Arab Church shrank numerically. ${ }^{4}$ Thus, 'Abu Qurrah and other Arab Christian theologians and church leaders responded to this cultural shift by developing a robust new literature to catechise the Christian community as Near Eastern society became Arabised and as Syriac was relegated to the liturgy (see Griffith 1996, 2002). The development of Arabic Christian literature is an important chapter in the history of World Christianity. It is within this story that we recognise the importance of On the triune nature of God that was written originally in Arabic, and quoted from the Hebrew Scriptures, the New Testament and from the Qur'an. What then can we say about pre-Islamic Arab Christianity?

There are two major historical problems when ascertaining the presence or use of any Arabic scripture as a litmus test for the vitality of pre-Islamic Arab Christianity; firstly, there are no early primary Arabic Christian historical sources and Islam have been clearly debunked. The best and most widely utilised research on this is that of Bulliet (1979). secondly, there is no agreed upon definition of 'arabness' in antiquity. The first problem is, as Robert Hoyland (2001:10) has noted: 'There is no Arabian Tacitus or Josephus [or Eusebius!] to furnish us with a grand narrative of Arab Christian identity'.We are left with 4 th and 5th century Greek and Latin Christian historians who look Eastward with their own particular pejorative judgements on the Arabs, or 9th and 10th century Muslim sources who look back several generations with their own perspectives, or even later medieval Syriac sources that reflect on several generations of Syriac Christianity. ${ }^{5}$ This lacunae occurs primarily because Arabic does not appear as a written language in some form until the 6th or 7th centuries. Prior to this, Arabs utilised other languages to put their words into writing.

Robert Hoyland has noted that based upon the thousands of remains of graffiti scattered throughout the Near East, the Arabs living from Hadramat (what we now know as Yemen) all the way up to the middle of the Tigris-Ephrates valley area (in what is now Iraq and Syria) all shared some form of an oral Arabic dialect but utilised multiple written languages of the broader world: Aramaic and Nabatean, in particular (Hoyland 2001:198-199). From the 3rd through the 5th centuries CE we know that Christian Arabs were also using Greek, Latin and Syriac in written forms. In addition, Irfan Shahid's magisterial study of the Arabs from the Roman period through the 6th century has noted numerous examples of Arabs using Greek and Latin as a part of their ecclesiastical life. For example, Christian bishops often adopted 'Christian' names at their consecrations. In the 4th century we find several important Arab bishops who took on Helenised or Christianised names: Theotimus the Arab and Moses the Arab both who were responsible for oversight of the Tanukhids (Shahid 1984:76-77). ${ }^{6}$ Another important example of how the arabness of the Arabs was subsumed into the broader dominant languages around them is in reference to the 6th century Arab Ghassanid King al-Harith ibn Jabala (529-569), who was known in the Greek histories as 'Arethas, Phylarch of the Arabs' (Shahid 1957:39-65, 362-382).

Shahid has sifted carefully through the Greek, Latin, Syriac and Arabic sources to look for evidence of an Arab Church. He has argued that the Arab Christians used the lingua franca of the major empires of the day to participate in either international trade, politics, or communicate with their respective church structures. In the case of those Christian Arabs who were under the authority of the Western Church from Constantinople, their linguistic records were recorded in Greek. For those whose authority was the Eastern Antiochene or Assyrian Church of the East, then their adopted language became Western or Eastern Syriac. This meant that the pre-Islamic Christian communities left no direct Arabic Christian literature or Bible, but made full use of the ecclesiastical literature that was readily available to them in their immediate locales.

5.I have already reviewed the role of the ecclesiastical historians in their perceptions of 'the Arabs' (see Grafton 2008). For a review of the Syriac sources, see Shahid (1998).

6.In addition to this specific reference, see Shahid's works in this project (1984a, $1984 b, 1988,1989,1995,2002,2009)$ 
Because Arabs lived on the edges of or between the Roman and Persian empires, they tended to not only adopt the language of the surrounding civilisations but their culture as well. In the case of Rome, the historian Philip K. Hitti (1957:253) calls this the 'thin veneer of Hellenization'. Following the annexation of Petra by Rome in 106 CE and conquering of Palmyra in $262 \mathrm{CE}$, the Arab communities of the east began to assimilate into Roman culture because they were now under the aegis of Rome and at least Palmyrians were granted citizenship by Caracalla (r. 198-211 CE).

This shift from a local culture to an imperial culture can be seen clearly through the history of the Domna family of Syria. Julia Domna was from an Arab family in Emesa (contemporary Homs). She married the Roman Emperor Septimus Severus. Julia was known for her love of philosophy and came from a family that adhered to the local Arab pantheon of gods and goddesses. Her impact on Roman society is legendary (see Levick 2007). Another important Arab that was vital to the life of the Roman Empire was Marcus Julius Philippus who was crowned Roman Emperor in $244 \mathrm{CE}$ and reigned a short eight years. 'Philip the Arab', as he became known, was born within the Roman Province of Arabia. Whilst his early life and culture have only come under recent scrutiny, his story underlines a particular problem that historians face. ${ }^{7}$ That is, how do we exactly define 'arabness'? In Philip's case, it was a political designation, noting his birth and origin from the Roman Province of Arabia.

Philip leads us to the second historical problem that we have regarding the identity of the pre-Islamic Arab Church: there is no universal agreement amongst the sources on just who are 'the Arabs'! Because we are relegated to 'outsider' definitions and views of the Arabs by Western Greek and Latin Christians or later Syriac and Arabic sources over the course of several centuries, there is no one common definition of what exactly an Arab was. Whilst the modern definition of an Arab is linguistic in reference to those whose mother tongue is Arabic, in antiquity most references focused upon their particular unique culture (Grafton 2009:189-193).

As this author has already noted elsewhere, the 5th and 6th century Christian Melkite historians, following the footsteps of Eusebius of Caesarea, made particular pejorative judgments about the Arabs as uncultured barbarians and did not give heed to any Christian presence. This ecclesiastical view has been perpetuated by later Western historians even to the present. Jan Retsö's important work, The Arabs in antiquity, has relegated pre-Islamic Christianity amongst the Arabs to a few minor references, indicating that the 'Arabs seem to disappear completely' around 400, only then to reappear in the classical Muslim sources of the 8th and 9th centuries (Retsö 2003:518)! ${ }^{8}$ To be fair to Retsö, the historical sources are not explicit in their terminology. The problem is that the designation of Arab itself was not a fixed term and often served more as a Western derogatory reference than

7.The only accessible biography in English is that of Zahran (2001). Another study done in Germany but not accessible to this researcher is Körner (2002).

8.Another detailed but shorter review of the Arab tribes without clear mention of any kind of Christian identity is A. Grohmann, 'Arabs', Encylopedia of Islam, 2nd edition. as a clear designation of ethnicity or language (Grafton 2008:190-191). Retsö does rightly point out, however, that the words 'arab (in Arabic), saraceni (in Greek and later Latin), and tayyaye (in Syriac) were moveable designations that did not accurately describe the actual people living in the Roman Province of Arabia, who were only recognised by their legal status after $106 \mathrm{CE}$. The point here is that the 'outsider' sources make reference to Christianity in the Near East or even within the province of Arabia, but do not explicitly link this with the Arabs.

Because of these two problems, no Arab Eusebius and no clear definition of arabness, we have difficulty in uncovering the story of the Arabs, and especially the Arab Christians, from their own perspective in antiquity. It is not until the 6th century that we find Arabs using the Arabic script to leave any form of cultural self-identification. The poetry of pre-Islamic Arabs is the first genre of indigenous literature where the history of the Arabs can be gleaned from their own perspective; and even so, most of the collections of these 6th century poets are the result of 8th century editors (Hoyland 2001:212-220).The general murkiness of the historical sources on the Arabs is difficult enough, let alone our inquiry into what Arab Christianity actually signifies. Nevertheless, if we look closely we find the evidence.

\section{Centres of pre-Islamic Arab Christianity}

The canonical book of Acts of the Apostles makes reference to the Arab Jews or proselytes present in Jerusalem at Pentecost who became Christians (Acts 2:11). Acts does not define the term Arab, but if we accept this document as even somewhat historical, it at least provides evidence for Arab Christians at the earliest point of Christianity in the late 1st century CE (Grafton 2009:201). For the purposes of this brief overview of pre-Islamic Arab Christianity we will limit ourselves to the political definition of Arabness. In 106 CE the Roman Empire annexed the kingdom of Petra and created the province of Arabia whose boundaries variously shifted throughout the Near East up until the loss of the Eastern provinces (later called the province of Oriens) by the Byzantine Empire to the Arab Muslims at Yarmuk in 636 CE. Whilst it is certainly beyond the scope of an article of this size to provide a detailed history of the Arab Christianity, it will be sufficient to note a number of important historical references to centres of late antique Arab Christianity, as well as histories of Arab Christian tribes within the province of Arabia.

The ecclesiastical historian Eusebius of Caeserea makes numerous references to Christianity within the province of Arabia. He refers to Bishop Beryllus of Bostra, who was involved in the early Christological controversies (Eusebius n.d). This reference has led to the unfortunate later association of the province with heretical movements and its derogatory appellation of heraxferaesis. ${ }^{9}$ Eusebius goes on to

9.This argument was advanced by Woodward (1916). Whilst there are interesting and important theological identities at play in the various Arab Christian communities in the province of Arabia, especially after the Council of Chalcedon, this article will not focus on the theological controversies but only the history of the Christian will not focus on the theological controversies but only the history of the Christian
presence. Discussions and judgements about the 'orthodoxy' or 'heterodoxy' of presence. Discussions and judgements about the 'ortho
these various communities are left aside for another time. 
mention the presence of five Arab bishops to the Council of Nicea (325): Nicomachus of Bostra, Kyrion of Philadelphia ('Amman), Gennadios of Esbus (Hexban), Severus of Dionysias (Suwaida), and Sopatros of Aere in Batanea. He notes four Arab bishops at the Council of Constantinople (381) and twenty at the Council of Chalcedon (451) (Shahid 1984a:330-337). Eusebius' records of the substantial Christian presence are supported by the archaeological evidence of the remains of numerous large churches in Bostra, the provincial capital of Arabia (Bowersock, Brown \& Grabar 1999:348).

The earliest church structure uncovered in Arabia, however, would be the chapel at the Roman outpost of Dura Europos on the Euphrates River. This church was excavated by French and American archaeologists in the 1920s and 1930s and is dated to 256 at latest. It should be noted that this is before the rise of Constantine. Whilst it cannot be proved that this was either an indigenous Arab Christian community or was utilised by Roman Christian soldiers from the Legion Cyrenaica; nevertheless, its presence does note an established and public Christian presence in Arabia by the middle of the 3rd century even before the legality of Christianity in the empire (the classic study is Rostovtzeff 1932; see also Dirven 1999). The remains of paintings found in the synagogue of Dura Europos demonstrate clear Persian influence, as well as the use of the Syriac script by locals.

Another important Christian church from this period, although technically outside of the province of Arabia and located in the province of Euphratensis (previously a part of Syria Coele), was the shrine of the soldier martyr Sergius at Rusafa in the Syrian Desert just west of the Euphrates River. His martyrdom took place during the Diocletian persecutions and the burial site quickly became a shrine. By the 5 th century it was the site of a bishopric. It became known as Sergiopolis by the Byzantines, but Rusafa remained an important pilgrimage site for Arab Bedouin communities (Bowersock, Brown \& Grabar 1999:676).$^{10}$ However, perhaps the largest Christian church of Arabia was the cathedral in Najran, southern Arabia. Najran became a prominent miaphysite center of Christianity until its cathedral was razed by the Yemenite Jewish leader DhuNuwas in around 520 CE. This attack prompted an invasion by the Christian Ethiopic King Abraha, who killed DhuNuwas and re-consecrated the churches in Najran. Abraha then continued north to attack Mecca but was repulsed, according to the Qur'an by a miracle of God (al-Fil 1-5).

It is still debated as to whether there was a Christian community of any size in Mecca. The Sira (biography) of Muhammad by Ibn Ishaq from the 8th century notes that Muhammad protected the icon of Mary and Jesus in the Kaba from destruction. This has prompted the belief that there was some form of Christian presence and worship there. Given the role of Mecca as a trading post between Najran, Ethiopia and the northern caravan routes into Petra and Bostra, it 10.The most recent important study done on Rusafa is Fowden (1999). is highly possible that this was the case. In addition, the reference in the Sira to Ibn Waraqa, the friend of Muhammad and cousin of his first wife Khadija, as a Christian 'who had studied the scriptures' (Guillaume 1955:83) has added to the speculation that Christians were present. However, the most convincing research to date has demonstrated that if there were Christians in Mecca, they were more than likely slaves from other Arab Christian tribes who had been sold to owners then in Mecca rather than an established community (Osman 2005:71-74).

Contrary to the small number of Christians in the Hijaz region of Mecca by the 6th century, we know of several prominent Arab tribes from the 3rd to the 6th centuries who converted to Christianity en masse and served as allies of the Byzantines or Persians. These were the Tanukhids, the Salihids, the Lakhmids, Kinda, and the Ghassanids. They are referred to in a variety of sources; secular and ecclesiastical Greek, Western and Eastern Syriac and Muslim Arabic. The Tanukhids, led by Queen Mawiyya in the 4th century, revolted against Rome and wrested a treaty that provided for the consecration of a bishop Moses, who would specifically serve as the Arabs' bishop (Sozomen n.d; see also Trimingham 1978:3-10). The 5th century saw the rise of the powerful Ghassanids, who ultimately converted to the nonChalcedonian Miaphysite confession of Christianity against the wishes of the Byzantine Emperor Justinian. The standard research on the role of the Ghassanids within the imperial Christian politics of the day is still Theodore Nöldeke's Die Ghassânishcen Fürstenausdem Hause Gafna's (Nöldeke 1887). Finally, it has long been noted that the Lakhmids followed the theological views of the East Syriac Assyrian Church of the East and lived under the Sassanian Empire. Thus, whilst the Lakhmids were Arab Christians, their 'heretical' association with the 'Nestorian Church' in the Persian Empire pitted them against both Byzantium and the Ghassanids. This is a fascinating tale waiting to be told in all of its passion and drama.

The previous record of ecclesiastical bishoprics, structures and tribal identities underlie the Arab Christian narrative. However, the most important record of Arab Christianity was the 'Holy Men'. These monastics and ascetics wandered Arabia as well as served as a beacon for Arab Bedouin tribes and became the most important beacons of the light in the wilderness. Peter Brown's seminal article, 'The rise and function of the Holy Man in late antiquity', carefully reveals the importance of the monastics and ascetics for the development of Christianity in the East (Brown 1971:80-101). ${ }^{11}$

Scattered throughout the Greek, Latin, Syriac and Arabic historical sources we find stories of these hermits and ascetics who became magnets for local communities. The most

11. Whilst there are certainly records of the Holy Women within this tradition, we will use the masculine form both in reference to Brown's article, as well as in direct reference to the male examples used within the historical sources used here regarding Arabia. However, there have been several important studies on the role of Holy Women in Christian late antiquity, including Susanna Elm (1994) and Stephen J. Davis (2001). 
famous of these was Simon the Stylite, whose legendary life upon a pillar led to the development of a pilgrimage site and veritable city that grew up around him in what is now northwest of Aleppo, Syria. Within the province of Arabia, however, we find several important wandering monks who engaged both the sedentary and bedouin Arab communities. In his Vita Hilarion, Jerome recalls the miracles and holy deeds of this monk in the Negev and Sinai during the 4th century (Jerome n.d.). The ecclesiastical history of Sozomen provides a full list of the monastics throughout the Near East from Egypt up to the territory of the Persians (Sozomen n.d.). We have already been introduced to the Monk Moses who was known 'for performing the divine and miraculous signs' amongst the 'Saracens' of Arabia. He ultimately became recognised as the Bishop of the Tanukhids under Queen Mawiyya. Another important 6th century monastic serving amongst the Arabs within Persian territory was Ahudemah (Shahid 1995:152). Within the Syriac literature we find moving call narratives of Arab tribal leaders who gave up their worldly life for the monastic calling, including Dawud the Salihid and Nu'man of Hira of the Lakhmids (Shahid 1989:161-164, 297-300). Of course, throughout the later Arab Muslim literature in the biography of Muhammad we also find the important story of Bahira the monk who meets Muhammad as a young boy in the late 6th century. The use of this story within later Islamic literature provides evidence for the deep-seated traditions of these Holy Men within the communities of Arabia (Guillaume 2009:79-81).

What is important about these Holy Men (and Women) for the purposes of this article, is their role in preaching and teaching amongst the illiterate but multilingual communities throughout habitable northern Arabia. Sidney Griffith writes that whilst there may be no evidence for a written Arabic Bible, there certainly was an active faith life organised by the monastics of the desert who engaged the local communities. As Griffith (2013) notes:

Preaching is a function of the liturgical life of Jews and Christians, and while it is essentially an oral function, homilies, sermons and instructions also circulated in writing and, like the scriptures which they south to interpret and apply to daily life, they could also be recited in liturgical settings.And so it is that in the Syriac-speaking Christian communities, with whom the Arabic-speaking Christians of Muhammad's and the Qur'an's milieu were largely in common, a fairly large body of written homiletic material has been preserved ... (p. 92)

This homiletical material finds its record in Syriac literature as a standard form of interpreting and retelling scripture.It was recited, and most certainly was used, within the liturgies used by the Arabs (see e.g.Vööbus 1973:235-237). Thus, the Arabs had no written language of their own; however the Syriac homiletical material on the Bible would have been recited in public gatherings of liturgical settings.

Griffith goes on to note that much of this homiletical and liturgical material is in Syriac sources, but it is also found within the Qur'an. He posits that perhaps the best reference for the pre-Islamic biblical tradition of Arab Christians might just be the Qur'an itself! In fact, the biblical stories and traditions found in the Qu'ran might certainly be the 'biblical subtext' of the Qur'an which the Qur'an critiques (Griffith 2013:56). ${ }^{12}$ Here, Griffith argues against the prevailing previous Western scholarship, that the Arabian Peninsula was a territory rife with Christian heresy and religious sects, resulting in an Islam that adopted the Arabian heresy as its predominant view of Jesus. Rather, he argues that as the earliest document in Arabic with reference to Arab Christianity, the Qur'an is responding to a well attested presence of Christian 'mainline' Greek Melkites, West Syriac Jacobites and East Syriac Nestorians:

'[T] he Qur'an assumes that its audiences is thoroughly familiar with Jewish and Christian, canonical and noncanonical, scriptural and non-scriptural prophetic lore' that was active through the preaching of the 'holy men'. (Griffith 2013:26)

The Qur'an then provides its own prophetic critique, not only of polytheist Meccan Arabian society, but a theological argument against the beliefs of prominent Arab Jews and Arab Christians. Griffith accepts that the Qur'an advances its own theological position of a strict monotheism and what he calls its 'prophetology', rather than the retelling of a heterodox of heretical Christian traditions of errant monks (Griffith 2013:62). The Qur'anic references to various biblical traditions then should be viewed as its own theological critique of an active and vibrant oral Arab Christian tradition.

\section{Conclusion}

\section{A reassessment of the Arab Church}

After having reviewed the important scholarship and debates about the Arabic Bible and the presence of pre-Islamic Arabic Christianity in non-Arabic sources from the first to the 7 th century, what are we to say?

J. Spencer Trimingham, in Christianity among the Arabs in pre-Islamic times argued that the Syrian and Arabian desserts were home to a wide variety of Christian monastics and 'Holy Men' (and Holy Women) who served as the chaplains for indigenous Arab tribes.Yet they failed to indigenise the faith from a Syriac cultural base to that of the late antique arabness (Trimingham 1979:309-310). In Trimingham's estimation, the Arabs took advantage of the Christian monastic as a talisman, as part of a superstitious 'holy man cult' (Trimingham 1979:233). Christianity, he argued, did not penetrate into the lives of the Arabs primarily because the monks did not translate the Bible into the vernacular and inculcate Arab culture with biblical values and tradition. Trimingham's argument serves as an example of the Western Protestant assumptions outlined in the introduction of this article. It is clear that the earliest Arabic biblical texts can only be dated to the 9th century at the earliest (that is after the coming of Islam). This, however, does not necessarily imply that the Arab Christianity was weak and ineffective simply because it did not have an Arabic Bible and did not develop 12.Here Griffith utilises the term as originated by Gabriel Said Reynolds (2010). 
into an important representative Christian presence in late antiquity.

William A. Graham's work, Beyond the written Word: Oral aspects of Scripture in the history of religion, provides a helpful reminder that this Western Protestant assumption of a sacred text is not necessarily the only way that scripture is fixed into a community. Graham rightly argues that scripture may become central through oral recitation and through public worship and liturgy. This was certainly the case amongst the Melkite, Jacobite and Nestorian Arab communities of Arabia.

How do we abandon the prejudice that persons, who encounter scripture through its oral reception, its recitation, or chanting, or even by seeing its stories portrayed in visual images, are somehow less scriptural or orthodox than those who read the silent pages for themselves? How do we recognise that even for someone who is highly literate scriptural words that are spoken, recited, or chanted have an impact different from that of the written text read in privacy or silence? (Graham 1987:163)

Graham reminds us that a public recitation of scripture within a community can serve as an important identity marker. It is clear that the Arabs of the 7th century developed a truly clear Arabic recitation that served to unify them (see the Qur'an, Yusuf 1).

It should be recognised that the acceptance of the Qur'an as the dominant scripture of the Arabic language by the middle of the 7 th century created unique problems for the development and use of a public Arab Christian text. As Kenneth Cragg famously wrote, Arab Christians are linguistically defined by a language that is 'bound over to the Qur'an' (Cragg 1991:65). To put it another way, as the Qur'an has served as the standard of the Arabic language since its own binding, Arab Christians have had to engage in their own self-discovery of what it means to be Arab apart from the arabnessof the Qur'an. For some Arab Christians this has meant upholding the Islamic tradition as one important Arab cultural legacy. For others it has meant jettisoning the Arab veneer and looking for the pre-Islamic identities of the Phoenicians or Pharaohs. At other points in history, Arab Christians have tried to define their Arabness as an imperial imposition that has been forced upon their previous own cultural identities.

This record of an Arab Christianity as revealed through both the imperial languages and cultures of Rome, Byzantium, Persia and later Islam, demonstrates that whilst we find no Arab Bible, there is a long sustained Arab Christian presence in the Near East that was an active participant in the early days of the ecumenical creeds of the church, thrived under Arab Christian tribes and communities, organised important social, political and religious centres, and was supported by an active monastic and spiritualistic tradition that passed on the faith through preaching and stories of the Bible.

\section{Acknowledgements Competing interests}

The author declares that he has no financial or personal relationship(s) that may have inappropriately influenced him in writing this article.

\section{References}

Atiya, A.S., 1955, The Arabic manuscripts of Mount Sinai, Johns Hopkins University Press, Baltimore.

Bowersock, G.W., Brown, P. \& Grabar, O. (eds.), 1999, Late antiquity: A guide to the postclassical world, Belknap, Cambridge.

Brown, P., 1971, 'Rise and function of the Holy Man in late antiquity', The Journal of Roman Studies 61(1), 80-101. http://dx.doi.org/10.2307/300008

Bulliet, R.W., 1979, Conversion to Islam in the medieval period: An essay in quantitative history, Harvard University Press, Cambridge. http://dx.doi.org/10.4159/ harvard.9780674732810

Chabot, J.B., 1849, Chronique de Michel le Syrien, National Imprimerie, Paris.

Cragg, K., 1991, The Arab Christian, Westminster/John Knox, Louisville.

Davis, S.J., 2001, The cult of Saint Thecla: A tradition of women's piety in late antiquity, Oxford University Press, New York.

De Lagarde, P., 1963, 'On the supposed Latin origin of the Arabic version of the Gospels', Register of Literature and Science of the Catholic University of Ireland 4, 241-259.

De Lagarde, P., 2009, The Coptic Pentateuch and Arabic gospels, Gorgias, Piscataway.

Dirven, L., 1999, The Palmyrenes of Dura-Europos: A study of religious interaction in Roman Syria, Brill, Leiden.

Dodge, B., The Fihrist of al-Nadim: A tenth-century survey of Muslim culture, Columbia University Press, New York.

Elm, S., 1994, Virgins of God: The making of asceticism in late antiquity, Oxford University Press, New York.

Eusebius, n.d., 'Ecclesiastical history', XX.2 and XXXIII.1, in Christian classics ethereal library, viewed from http://www.ccel.org/ccel/schaff/npnf201.iii.xi.xxxiii. html?highlight=bostra\#highlight

Fowden, E.K., 1999, The Barbarian plain: Saint Sergius between Rome and Iran, University of California Press, Berkeley.

Gibson, M.D., 2003, An Arabic version of the Acts of the Apostles and the seven Catholic epistles: From an eighth or ninth century ms. in the convent of St. Catharine on Mount Sinai with a treatise on the triune nature of God, with translation from the same codex, Gorgias, Piscataway.

Grafton, D.D., 2008, “The Arabs" in the ecclesiastical historians of the 4th/5th centuries: The effects on contemporary Christian-Muslim relations', HTS Teologiese Studies/Theological Studies 64(1), 177-192. http://dx.doi.org/10.4102/hts. v64i1.14

Grafton, D.D., 2009, 'The Arabs of Pentecost: Greco-Roman views of the Arabs and their cultural identity', Theological Review 30(2), 189-193.

Grafton, D.D., 2013, 'The politics of pre-Islamic Arab Christianity in contemporary Western scholarship', Theological Review 34(1), 3-21.

Graham, W.A., 1987, Beyond the written word: Oral aspects of scripture in the history of religion, Cambridge University Press, New York.

Griffith, S.H., 1985, 'The Gospel in Arabic: An inquiry into its appearance in the first Abbasid Century', Oriens Christianus 69, 126-167.

Griffith, S.H., 1996, 'The view of Islam from the monasteries of Palestine in the early 'Abbasid Period: Theodore Abu Qurrah and the Summa Theologiae Arabica', Islam and Christian-Muslim Relations 7(1), 9-28. http://dx.doi. Arabica', Islam and Christian-M A
org/10.1080/09596419608721064

Griffith, S.H., 2002, The beginnings of Christian theology in Arabic: Muslim-Christian encounters in the early Islamic period, Ashgate, Burlington.

Griffith, S.H., 2013, The Bible in Arabic, Princeton University Press, New York.

Grypeou, E., Swanson, M. \& Thomas, D. (eds.), 2006, Theencounter of Eastern Christianity with early Islam, Brill, Leiden.

Guillaume, A., 1955, The Life of Muhammad, Oxford University Press, Oxford.

Hitti, P.K., 1957, History of Syria, Macmillan, London.

Hoyland, R.G., 2001, Arabia and the Arabs, Routledge, New York.

Jerome, n.d., 'The life of St. Hilarion', 1-47, NPNF 2nd series, vol. 6, 303-315, in Christian classics Ethereal library, viewed from http://www.ccel.org/ccel/schaff/ npnf206.vi.ii.html

Kachouh, H., 2008, 'The Arabic versions of the Gospels', PhD dissertation, University of Birmingham.

Kachouh, H., 2011, The Arabic versions of the Gospels and their families, De Gruyter Berlin. http://dx.doi.org/10.1515/9783110228595

Körner, C., 2002, Philippus Arabs: ein Soldatenkaiser in der Tradition des Antoninisch-Severischen Prinzipats, De Gruyter, Berlin. http://dx.doi. org/10.1515/9783110857832

Levick, B. \& Domna, J., 2007, Syrian empress, Routledge, New York. 
Lewis, A.S. \& Gibson, M.D., 1893, How the codex was found: A narrative of two visits to Sinai, from Mrs. Lewis's journals 1892-1893, Macmillan and Bowes, Cambridge.

Metzger, B.M., 1977, Early versions of the New Testament, Clarendon, Oxford. http:// dx.doi.org/10.1093/acprof:oso/9780198261704.001.0001

Nöldeke, T., 1887, Die Ghassânishcen Fürstenausdem HauseGafna's, Akademie der Wissenchaftenzu Berlin, Berlin.

Osman, G., 2005, 'Pre-Islamic Arab converts to Christianity in Mecca \& Medina: An investigation into the Arabic Sources', The Muslim World 95(1), 71-74. http:// dx.doi.org/10.1111/j.1478-1913.2005.00079.x

P. -L.G., 1999a, 'Bostra', in G.W. Bowersock, P. Brown \& O. Grabar (eds.), Late antiquity: A guide to the postclassical world, p. 348, Belknap, Cambridge.

P. -L.G., 1999b 'Rusafa', in G.W. Bowersock, P. Brown \& O. Grabar (eds.), Late antiquity: A guide to the postclassical world, p. 676, Belknap, Cambridge.

Raheb, M., 2013, Sailing through troubled waters: Christianity in the Middle East, Diyar Publishing, Bethlehem, Palestine.

Retsö, J., 2003, The Arabs in antiquity: Their history from the Assyrians to the Umayyads, Routledge Curzon, New York.

Reynolds, G.S., 2010, The Qur'an and its biblical subtext, Routledge, New York.

Roggema, B., 2009, The legend of Sergius Bahira, Brill, Leiden.

Rostovtzeff, M., 1932, Caravan cities: Petra, Jerash, Palmyra, Dura, Oxford University Press, New York.

Samir, S.K., 1994,'The earliest Arab apology for Christianity (C. 750)', in S.K. Samir \& J.S. Nielsen (eds.), Christian Arabic apologetics during the Abbasid period (750-1258), pp. 57-114, Brill, Leiden.

Sanneh, L., 2008, Translating the message: The missionary impact on culture, Orbis, Maryknoll.

Schaff, P. (ed.), 1892, Jerome: The principal works of St. Jerome, Christian Literature Publishing Co, New York. (NPNF vol. 6), viewed from http://www.ccel.org/ccel/ schaff/npnf206.vi.ii.html

Shahid, I., 1957, 'Procopius and the Arethas', Byzantine Zeitschrift 50(1), 39-65; 362382.

Shahid, I., 1984a, Rome and the Arabs: A prolegomenon to the study of Byzantium and the Arabs, Dumbarton Oaks, Washington.

Shahid, I., 1984b, Byzantium and the Arabs in the fourth century, Dumbarton Oaks, Washington.
Shahid, I., 1988, Byzantium and the Semitic Orient: Before the rise of Islam, Dumbarton Oaks, Washington.

Shahid, I., 1989, Byzantium and the Arabs in the fifth century, Dumbarton Oaks, Washington.

Shahid, I., 1995, Byzantium and the Arabs in the sixth century, vol.1, parts 1 \& 2 Dumbarton Oaks, Washington.

Shahid, I., 1998, 'The Syriac sources for the history of the Arabs before the rise of Islam: An evaluation', (Rome: Pontificiolstituto Orientale), Symposium Syriacum VII, 323-331.

Shahid, I., 2002, Byzantium and the Arabs in the sixth century, vol.2, part 1, Dumbarton Oaks, Washington.

Shahid, I., 2009, Byzantium and the Arabs in the sixth century, vol.2, part 2, Dumbarton Oaks, Washington.

Smalley, W.A., 1991, Translation as mission: Bible translation in the modern missionary movement, Mercer University Press, Macon.

Sozomen, n.d., 'Church history', 6.38-34.37, NPNF vol. 2, 365-371, in Christian classics ethereal library, viewed from http://www.ccel.org/ccel/schaff/npnf202. iii.xi.xxviii.html

Sozomen, n.d., 'Ecclesiastical history', VI.38, NPNF vol. 2, 374, in Christian classics ethereal library, viewed from http://www.ccel.org/ccel/schaff/npnf202.iii. xi.xxxviii.html

Stine, P.C. (ed.), 1992, Bible translation and the spread of the Church: The last 200 years, Brill, Leiden.

Swanson, M.N., 1998, 'Beyond prooftexting: Approaches to the Qur'an in some early Arabic Christian Apologies', The Muslim World LXXXVIII (3/4), 297-319. http:// dx.doi.org/10.1111/j.1478-1913.1998.tb03663.x

Trimingham, J.S., 1978, 'Mawiyya: The first Christian Arab queen', The Near East school of Theology Theological Review 1(1), 3-10.

Trimingham, J.S., 1979, Christianity among the Arabs in pre-Islamic times, Longman, New York.

Vööbus, A., 1973, 'Discovery of new important "memre" of Giwargi, the bishop of the Arabs', Journal of Semitic Studies 18(2), 235-237. http://dx.doi.org/10.1093/ jss/XVIII.2.235

Woodward, E.L., 1916, Christianity and nationalism in the later Roman Empire, Longmans, London.

Zahran, Y., 2001, Philip the Arab: A study in prejudice, Stacey International, London. 